физической культуры. Она также включает в себя психолого-педагогическое сопровождение всех элементов образовательного процесса; образовательные технологии, в том числе программы, в которых студентов учат заботиться о своем здоровье, вести правильный образ жизни и отказываться от вредных привычек. Технологии также предусматривают организационную работу со студентами [8, с. 112-116].

И подводя итог вышесказанному можно с уверенностью утверждать, что современная система высшего образования в сфере физической культуры и спорта, безусловно, обладает серьёзным педагогическим ресурсом, позволяющим формировать из числа обучающихся в спортивном вузе будущих профессионалов в сфере ФКиС.

$$
* * *
$$

1. Барчуков И.С. Теория и методика физического воспитания и спорта: учебник / И.С. Барчуков. Москва: КноРус, 2012, 368 с.

2. Жиркова 3. С. Основы педагогического проектирования: учебное пособие для студентов высших учебных заведений / 3. С. Жиркова. Москва: Академия естествознания, 2014. с. 31

3. Загвязинский В. И. Теория обучения: современная интерпретация: учебное пособие для студентов высших педагогических учебных заведений / В. И. Загвязинский. Москва: Академия, 2001. 192 с.

4. Калимуллина О.А. Сущность содержательной среды дополнительного образования Вестник Казанского государственного университета культуры и искусств. 2019. № 2. С. 99-103.

5. Куликов Л.В. Психогигиена личности. Вопросы психологической устойчивости и психопрофилактики : учебное пособие/ Л.В. Куликов. Санкт Петербург: Питер, 2004, 464 с.

6. Медведева, С. А. Педагогическое проектирование физкультурно-спортивной деятельности будущих специалистов / С. А. Медведева // Проблемы современного педагогического образования. - 2019. - № 63-3. C. 68-72.

7. Н.К. Смирнов. Здоровьесберегающие образовательные технологии в современной школе- М.: АПК и ПРО, 2002. - $121 \mathrm{c}$.

8. Новиков Б.И. Физическая культура в системе ценностных ориентаций студентов / Б.И.Новиков, А.Г.Лушников // Спорт. Культура. Воспитание / отв. Ред. В.И. Столяров . Москва, Советский спорт, 2008, $112-116 \mathrm{c}$.

9. Ольховская Е.Б. Профессионально-образовательный потенциал физической культуры в высших учебных заведениях: монография / Е.Б. Ольховская, Т.А. Сапегина. Екатеринбург, издательствоРос. Гос. Проф. Пед.ун-та, 2008, 103 с.

10. Педагогика: учебное пособие для студентов педагогических учебных заведений / В. А. Сластенин [и др.]. 3-е изд. Москва: ШколаПресс, 2000. 512c.

11. Сериков В.В. Образование и личность. Теория и практика проектирования педагогических систем / М.: Издательская корпорация «Логос», 1999. - 272 с.

12. Щербина В.А. Применение инновационных технологий физического воспитания для формирования здорового образа и стиля жизни студентов /В.А. Щербина. Москва: Мпа Пресс. 2007, 319 с.

\title{
Pavlova N.Y. \\ Pedagogical support for the formation of communicative competence of students in the process of learning a foreign language
}

Khabarovsk state university of economics and law

(Russia, Khabarovsk)

doi: 10.18411/nrciz-02-2022-06

\section{Abstract}

The article is devoted to the issue of teaching a foreign language in a non-language university. The author draws the readers' attention to the pedagogical principles on which the learning process should be based. The university course of a foreign language is designed to be communicatively oriented and professionally directed, so its tasks are determined by communicative and cognitive needs of the students.

Keywords: communicative competence, teaching a foreign language, communicative approach, context-based learning. 


\section{Аннотация}

Статья посвящена вопросу обучения иностранному языку в неязыковом вузе. Автор обращает внимание читателей на педагогические принципы, на которых должен быть основан процесс обучения. Вузовский курс иностранного языка призван носить коммуникативно-ориентированный и профессионально-направленный характер, поэтому его задачи определяются коммуникативными и познавательными потребностями специалистов соответствующего профиля.

Ключевые слова: коммуникативная компетенция, преподавание иностранного языка, коммуникативный подход, контекстно-ориентированное обучение.

The mission of higher education today goes far beyond the mere transfer of knowledge. Higher education "is designed to train citizens who can think for themselves and see cultural differences as a good opportunity for fruitful dialogue" [1, c.22]. The purpose of higher education is to educate professionals capable of acting in business situations, professional growth and mobility in the context of the information society and the development of new knowledge-intensive technologies, with developed communicative competence.

The need for knowledge of a foreign language for a specialist with higher education is hardly worth proving. In a globalized economy, a foreign language is turning into the main production factor. "A specialist without knowledge of a foreign language is not a qualified, not a full-fledged specialist, even if he has technical knowledge" [2, c.8]. Today our students - future managers, specialists in the field of international relations - should know at least one, or two foreign languages.

A.A. Leontiev considers the process of mastering a foreign language to be " a way of actualization and realization of one's own personality, cultivation of creative beginning and ability to make independent decisions concerning life, activity, relations, formation of an active personal position" [3, c.34]. To build a speech act in a foreign language it is necessary to do an analysis of situations, goals, conditions, to address the interlocutor, the communicant must take into account information about age, social status, the official or unofficial nature of the conversation, etc. These speech operations contribute to the development of communicative competence. Communicative competence is considered in pedagogical literature a criterion of readiness for successful professional activity in all its functions: informative (as a means of receiving and transmitting information); interactive (as a culture of interaction); perceptive (aimed at penetrating and understanding the inner world of the interlocutor).

The final result of language learning is "the formation of students' practical skills of speaking (speaking), writing, listening, reading, the ability to apply these skills to express their thoughts, understanding the content and meaning of the text perceived by ear or eye, to solve communicative tasks" [4, c.14]. In other words, the final result of teaching a foreign language is the formation of communicative competence.

The study of the experience of teaching a foreign language in economic universities, as well as the practical experience of the author as a teacher led us to the conclusion that the teaching a foreign language is focused mainly on the accumulation of knowledge, namely enrichment of the vocabulary and grammar training. It is indisputable that lexical and grammatical skills are necessary to master the language, but learning, which is based only on memorization, unfortunately, does not develop students' creative activity, does not assume the formation of their communicative competence. The level of motivation is low under this approach, because the student does not see the application of the acquired knowledge in their future professional activities.

In recent years, the production sphere of communication has become much more complex. Economic, managerial, commercial, legal areas of professional activity have become widespread and developed. It is important for future specialists to master the skills of professional culture as a significant component of professional intercultural communication. The specific characteristics of social interaction, changed under the influence of time, revealed new components of training content, which imply mastering new professional "roles": organizer of joint enterprise, distributor of 
foreign firm, manager, able to negotiate and conclude contracts with representatives of other cultural and linguistic community, etc.

In view of the expansion of intercultural professional contacts the need of society for specialists in various fields, proficient in foreign languages increases. However, mastering a foreign language code, which allows successful intercultural professional interaction, implies mastering "professionally significant concepts of foreign language culture, which determine the specificity of social and business behavior, determined by the influence of historical traditions and customs, lifestyle, etc." [5, c.4]. Linguo-sociopsychological and cultural knowledge of foreign-speaking society, creating a wide context of intercultural communication forms perceptual readiness for effective intercultural business communication and, consequently, international professional cooperation.

The social order of the society determines foreign-language business communication as one of the most significant components of the content of training of non-philological specialists. The university course of a foreign language is designed to be communicatively oriented and professionally directed, therefore its tasks are determined by communicative and cognitive needs of specialists of the corresponding sphere [6].

When organizing the educational process aimed at the formation of communicative competence, it is necessary to rely on the principles of humanistic pedagogy: natural conformity, cultural conformity, social conformity, freedom conformity.

The founders of the principle of natural conformity are J.A. Comenius, J.-J. Rousseau, A. Disterweg, L.N. Tolstoy, who proclaimed the special importance of man as an element of nature, with his individual physical and mental features.

When studying a foreign language the process of education and upbringing should be based on the personal experience of the student. It is necessary to build an educational space having personal meanings for students, attracting them to research and independent learning.

In the logic of our study, an important principle is the principle of cultural conformity formulated by classical pedagogy, according to which the training, development of the student should go in the context of culture.

Culturally conformity is the principle according to which education must be relevant to modern culture and its features and requirements, aimed at cultural, spiritual, moral, and not only cognitive values. Simulation of real communication situations, taken from the context of history, culture, and professional activity, and their reflexive perception contribute to students' activity during classes, development of interest and participation in research work.

The principle of multicultural education (N.B. Krylova) determines the correspondence of educational content to the diverse cultures of society, which contributes to cultural selfdetermination and cultural identification of students. It defines the requirement to build an educational environment as multicultural without any dominance, as dialogue and interaction of cultures [7].

The principle of social conformity reflects the idea of the role of education in social reproduction of an individual, which corresponds to the ideas of society about an "ideal" member of society as a continuer and creator of spiritual and moral values.

In our view this principle determins the formation of the educational process on the basis of the social environment, having a "formative" influence on the personality of an individual, determining his relations with the society and self-realization.

The principle of freedom conformity (L.N. Tolstoy, K.N. Wentzel) determines the nonviolent nature of the teacher's impact on the student.

The essence of the principle of freedom conformity also lies in the release of internal creative forces of students, encouragement of their attempts to show freedom of judgment and behavior, freedom of cultural self-determination.

When organizing the educational process, focused on the formation of communicative competence by means of a foreign language, apart from the principles of classical pedagogy, it is necessary to rely on the principles that constitute the essence of the communicative approach in 
teaching foreign languages: person-centered communication, role organization of educational material and educational process, collective interaction, considering the context of professional activity.

The principle of person-centered communication implies the fusion of learning and communication, allows students to enter into communication at the level of personal meanings, revealing and realizing themselves as a person. Communication is the most important means of learning, but at the same time it is communicative activity in the target language that is the most important part of learning.

The principle of role-based organization of the learning process stimulates the motivation of speech acts of students. Role communication is an effective way to acquire communicative competence. Role communication is the basis of building the process of learning to communicate in a foreign language. Game techniques in teaching a foreign language refer to the most rational methods for the formation of communicative competence.

The principle of collective interaction is based on the laws of social psychology. Its essence is the organization of group (collective) actions, contributing to the internal mobilization of the personality of the learner. This principle defines such a way of organizing the educational process in which: a) students actively communicate with each other, exchanging educational information, expanding their knowledge, improving skills and abilities; b) there are favorable relations between the participants; c) the success of each is a condition for the success of others.

The principle of context-based learning plays an important role in higher education. The context is "a system of internal and external conditions of human behavior and activity, which affects the perception, understanding, and transformation of the subject of a particular situation, giving meaning and significance to this situation". [8, c.23]. Taking into account the context of future professional activity stimulates motivation to learn a foreign language, filling the content of education with personally significant meanings for students.

Humanistic pedagogy considers the processes of upbringing and education in their inseparable unity and integrity, since these processes are aimed at a person as a whole. The success of upbringing depends on the degree of mutual openness of the teacher and the student.

The role of education in the process of formation of communicative competence of students when studying a foreign language is great, but we must remember that the teacher should only help the student to find and develop his best qualities. Thus, we can conclude that pedagogical influence plays a priority role in the process of formation of communicative competence.

$$
* * *
$$

1. The New Mission of Higher Education // Bulletin of Higher Education. - 1998. - №12. - C. 22.

2. Ilyenkov, E. V. Philosophy. - M. : Publishing house Political Literature, 1996. -128c.

3. Leontiev, A. A. Thinking in a foreign language as a psychological and methodological problem / A. A. Leontiev // Foreign languages at school. - 1972. - №1.

4. Leontiev, A. A. Psychology of communication. - M. : The sense, 1997. - 351c.

5. Astafurova, T. N. Linguistic Aspects of Intercultural Business Communication. - Volgograd : Volgograd State University Press, 1997. - 108c.

6. Standard Program of Foreign Languages for Higher Education Institutions of Non-Language Specialties. MOSCOW: MOSCOW STATE UNIVERSITY, 1994. - 22c.

7. Krylova, N. B. Culturology of Education. - Moscow : People's Education, 2000. - 272c.

8. Verbitsky, A. A. Contextual learning and the formation of a new educational paradigm. - Zhukovsky: MIM LINK, 2000. $-41 \mathrm{c}$. 